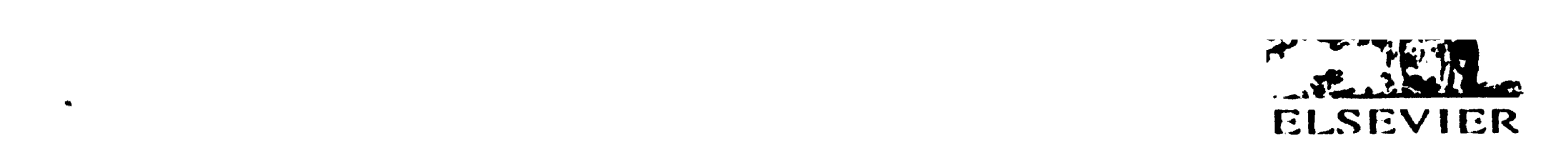

$11>_{3}$

\title{
Grassland converted to cropland: Soil conditions and sorghum yield
}

\author{
K.B. Laryea ${ }^{a, *}$, P.W. Unger \\ -International Crops Research Institute for the Semi-Arid Tropics (ICRISAT) \\ Patancheru. Andhra Pradesh 502324 . India \\ - US Department of Agriculture. Agriculture Research Service. Conservation and Production Research \\ Laboratory. Bushland. TX 79012 . USA
}

Accepted 7 September 1994

\section{Abstract}

An appropriate tillage system is needed for conversion of virgin lands or revegetated lands to croplands to ensure sustainable crop production. We compared the efrects of three tillage systems (viz. primary tillage with sweep implement (SW), moldboard plough (MB), and no-tillage NT)) on grain sorghum (Sorghum bicolor (L.) Moench) yield and some soil properties. The land had been used for growing mainly Blue grama grass (Bouteloua gracilis) and Buffalograss (Buchloe dactyloides) for over 50 years. A split-plot field experiment with SW, MB, and NT as main plots was conducted on a Pullman clay loam (Torrertic Paleustolls). Sub-plot treatments were (a) increased soil water content at planting by adding $114 \mathrm{~mm}$ of water $(P W+$ ), and (b) existing soil water content at planting (PW - ). Because of the surface mulch, more soil water was stored in the NT treatment than in either the SW or MB treatments. The increased stored water was also reflected in greater grain and stover yields for NT sorghum. Peak water extracted from soil by crop, as estimated from soil water content measurements, occurred during the vegetative stage at 60 days after emergence (DAE). It was greatest for NT sorghum, followed in order by SW and $M B$. Although grain and stover yields were larger with NT than with SW or MB, grain and $M B$. Although grain and stover yields were larger with NT than with SW or MB, grain and stover from $M B$ plots contained more nitrogen than those from $S W$ and $N T$ plots. Soil
organic carbon content at a depth of $0-15 \mathrm{~cm}$ was significantly greater $(P<0.05)$ under organic carbon content at a depth of $0-15 \mathrm{~cm}$ was significantly greater $(P<0.05)$ under
$\mathrm{NT}(1.40 \%)$ than under $S W(1.21 \%)$ or $\mathrm{MB}(1.25 \%)$. Ploughing increased soil nitrogen mineralization, with the result that $\mathrm{NO}_{3}^{-}-\mathrm{N}$ at a depth of $\mathrm{O}_{-1} 15 \mathrm{~cm}$ was larger under $\mathrm{MB}$ than under $N T$. The $\mathrm{NH}_{4}^{+}-\mathrm{N}$ content under the three tillage systems was highly variable. From a production viewpoint, a no-tillage system is better than $\mathrm{MB}$ or $\mathrm{SW}$ for converting revegetated land to cropland in locations where soil water is timiting.

Corresponding author.

* Contribution from USDA, Agricultural Research Service, Conservation and Production Research Laboratory, P.O. Drawer 10, Bushland, TX 79012, USA

0167-1987/95/\$09.50 01995 Elsevier Science B.V. All rights reserved SSDI $0167-1987(94) 00433-1$ 
production after over 50 years of grass vegetation, and (b) the effect of the tillage system on sorghum yield (both grain and above-ground biomass).

\section{Introduction}

Tillage is one of the major land preparation activities normally used to convert natural vegetation (forest, steppe, or grassland) to cropland. In most developing countries, large areas of virgin lands or revegetated lands in the fallow phase of shifting cultivation are presently being converted to cropland. Since 1985, about 14.3 million ha of highly erodible croplands have been put into a Conservation Reserve Program (CRP) in the USA for 10 years. Contracts in this program covering 1.9 million ha will expire in 1996. This land, or a portion of it, may be converted back to cropland. Because these are potentially highly erodible lands, their tillage and cropping systems are very important. Therefore, it is essential that appropriate tillage systems be used to convert these revegetated lands to croplands in order to ensure sustainable crop production and tolerable levels of wind and water erosion.

The selection of a tillage system for converting natural vegetation to cropland in any agroecological region depends, among other things, on soils, climate, natural vegetation, crops, and socio-economic factors. In developing countries, conversion to cropland may take the form of felling trees, stumping to remove roots, burning, and hoeing, either manually or using draft animals. On the other hand, burning is usually omitted in developed countries and machines and implements are used for both primary and secondary tillage operations. Where no-tillage is practised, herbicides are used to control weeds and sowing is done by cutting small slits or punching holes in the soil.

Tillage systems affect soil properties. For example, compared with conservation tillage, clean tillage results in the decline of soil organic matter content. This decline decreases soil aggregate stability and results in the deterioration of soil quality (Ramig and Mazurak, 1964). Because a number of factors (e.g. weather, incidence of pests and diseases, drainage, etc.) regulate crop growth and yield response, tillage may have a positive, negative, or zero effect on crop productivity. Thus, when precipitation is adequate and there is adequate soil water, good drainage, and adequate available nitrogen, the type of tillage does not influence grain yield. On the one hand, increased grain yields in conservation tillage systems, particularly no-till, compared with clean tillage, have been obtained in areas having limited precipitation and soil water (e.g. Baumhardt et al., 1985). On the other hand, conservation tillage resulted in lower crop yields in regions where precipitation was adequate-to-excessive, soil temperatures were low, weed control was poor, and soil drainage was poor (Hargrove and Hardcastle, 1984). The varying performance of tillage practice emphasizes the need to determine the appropriate tillage system for different agroecological niches and soils when converting natural vegetation into croplands. In this study, we examine (a) the effect of three tillage systems on some soil properties when land is converted to sorghum

\section{Materials and methods}

\subsection{Field experiment}

The field experiment was conducted on a Pullman clay loam with less than $1 \%$ slope at the experimental farm of the USDA-ARS Conservation and Production Research Laboratory at Bushland, Texas $\left(35^{\circ} 11^{\prime} \mathrm{N}, 102^{\circ} 5^{\prime} \mathrm{W}\right)$, in 1993 . The soil, which is classified as fine, mixed thermic Torrertic Paleustolls, has $392 \mathrm{~g}$ $\mathrm{kg}^{-1}$ sand, $316 \mathrm{~g} \mathrm{~kg}^{-1}$ silt, $292 \mathrm{~g} \mathrm{~kg}^{-1}$ clay, a cation exchange capacity of $18 \mathrm{cmol}$ $\left(\mathrm{P}^{+}\right) \mathrm{kg}^{-1}$ and an organic carbon content of $12.5 \mathrm{~g} \mathrm{~kg}^{-1}$ at $0-0.15 \mathrm{~m}$ depth. The experiment had a split-plot design with four replications. No-tillage (NT), primary tillage using a moldboard plough (MB), and primary land preparation with a sweep tillage implement ( $\mathrm{SW}$ ) were the main plot treatments. Main plot size was $13.4 \mathrm{~m} \times 9.1 \mathrm{~m}$. The NT plots were sprayed with Roundup' (glyphosate, $\mathrm{N}$ (phosphonomethyl) glycine), in the form of its isopropylamine salt, at the rate of $2.31 \mathrm{ha}^{-1}$ to kill the grass. Therefore, the surface of NT plots was not disturbed, except for the small disturbance that occurred during sorghum planting with a planter having double disk openers. Weed control after the primary tillage operation was done by spraying all plots three times with Roundup at the rate of 1.2$2.31 \mathrm{ha}^{-1}$ during the period from the imposition of treatments to the date of sorghum planting. In addition, $2.24 \mathrm{~kg} \mathrm{ha}^{-1}$ propazine (2-chloro-4,6bis (isopropylamino)-s-triazine ) pre-emergence herbicide was applied to all plots after sorghum planting. Sub-plot $(9.1 \mathrm{~m} \times 3.7 \mathrm{~m})$ treatments were (a) increased soil water content at planting by adding $114 \mathrm{~mm}$ of water $(\mathrm{PW}+)$, and (b) existing soil water content at planting ( $\mathrm{PW}-$ ). A buffer zone of $9.1 \mathrm{~m} \times 2.7 \mathrm{~m} \mathrm{sep}$ arated the nonwetted and prewetted sub-plots. A 3.0-m-long turning area was left at the end of each plot.

In the semi-arid regions of the southern Great Plains, a well-adapted cropping system is a wheat (Triticum aestivum L.)-sorghum-fallow rotation. This system results in two crops (one wheat and one sorghum) in a 3-year period, with a fallow period of about 330 days between harvest and planting of successive crops. The tillage treatments were imposed on 22 July 1992, which allowed about 330 days of fallow for profile water storage and microbial conversion of organic nutrients to inorganic forms prior to planting the sorghum crop in the 1993 cropping season.

Soil samples were collected from six sites in each plot on 10 May 1993 before the sub-plot treatments were imposed. The samples were coliected from depths of $0-15,15-30,30-50,50-75,75-100$, and 100-125 cm. The samples were ob-

' Mention of a trade name or product does not constitute a recommendation or endorsement for use by the USDA, nor does it imply registration under FIFRA as amended. 
tained with $5.7-\mathrm{cm}$ diameter steel tubes and a tractor-mounted coring machine. The soil samples from each depth in each plot were composited. Two additional soil samples, from two sample extraction tubes, were collected from each tillage treatment and kept in a refrigerator for $\mathrm{NH}_{4}^{+}-\mathrm{N}$ and $\mathrm{NO}_{3}^{-}-\mathrm{N}$ determinations. Access tubes were installed in all sub-plots to a depth of $1.50 \mathrm{~m}$ for determining soil water contents and evapotranspiration data with a neutron probe.

Sorghum hybrid DEKALB 46 was sown at $75 \mathrm{~cm}$ row spacing on 15 June 1993, using a planter with double disk openers, at a rate to obtain 60000 plants ha ${ }^{-1}$. Thereafter, soil water content was measured by neutron probe at 10,29, 54,61, 68,75 , and 95 days after emergence (DAE) of seedlings. Sorghum heads (panicles) and stover from areas of $3.75 \mathrm{~m} \times 3.0 \mathrm{~m}$ were harvested from each sub-plot at 115 DAE. From each sub-plot treatment, a sub-sample of stover was then weighed, oven-dried at $60^{\circ} \mathrm{C}$, and weighed again to determine moisture content and dry weight of the above-ground biomass. Panicles from each sub-plot were counted, air-dried, and threshed, and the grain was weighed.

\subsection{Laboratory measurements}

With the exception of the samples kept in the refrigerator, soils from the plots were air-dried and ground to pass through a sieve with $2-\mathrm{mm}$ round holes. Duplicate determinations were made on each sample for $\mathrm{pH}$ (soil reaction) on a 1:1 soil:water and a $1: 1$ soil:0.01 $\mathrm{M} \mathrm{CaCl}_{2}$ suspension. Organic carbon content was determined by the modified Walkley-Black procedure (Jackson, 1958). Each refrigerated soil sample was mixed thoroughly and $10 \mathrm{~g}$ was used for the extraction of exchangeable $\mathrm{NH}_{4}^{+}-\mathrm{N}$ and $\mathrm{NO}_{3}^{-}-\mathrm{N}$ using $2 \mathrm{M} \mathrm{KCl}$. Exchangeable $\mathrm{NH}_{4}^{+}-\mathrm{N}$ was determined by the indophenol blue procedure (Keeney and Nelson, 1982). Exchangeable $\mathrm{NO}_{3}^{-}-\mathrm{N}$ was determined by the hydrazine reduction method (Kampshake et al., 1967). Harvest index was calculated as the mass of grain as a percentage of total biomass (grain + stover) harvested from the $3.75 \mathrm{~m} \times 3.0 \mathrm{~m}$ area. Grain weight was determined by weighing 1000 grains. Samples of grain and stover were ground, and total nitrogen content was determined by digestion of a $0.20-\mathrm{g}$ sample ( $<40$-mesh) in a Folin-Wu digestion tube with $1.0 \mathrm{~g}$ of salt-catalyst mixture $\left(100 \mathrm{~g} \mathrm{~K}_{2} \mathrm{SO}_{4}: 10 \mathrm{~g} \mathrm{CuSO}_{4} .5 \mathrm{H}_{2} \mathrm{O}: 1 \mathrm{~g} \mathrm{Se}\right)$ followed by $5 \mathrm{ml}$ concentrated $\mathrm{H}_{2} \mathrm{SO}_{4}$ (Nelson and Sommers, 1973). Ammonium in the digestate was determined using the autoanalyzer procedure described in Technicon Autoanalyzer II (1977).

The data were statistically analyzed as a split-plot design using the GLM procedure of the Statistical Analysis Systems Institute Inc. (1989). The least significant difference (LSD) test and standard errors (SE) are used to show which differences are significant at $P<0.05$.

\section{Results and discussion}

\subsection{Profile water storage}

Water content in PW - and PW + sub-plots versus days after emergence (DAE) are presented in Figs. 1 and 2. Between 22 July 1992 when the treatments were

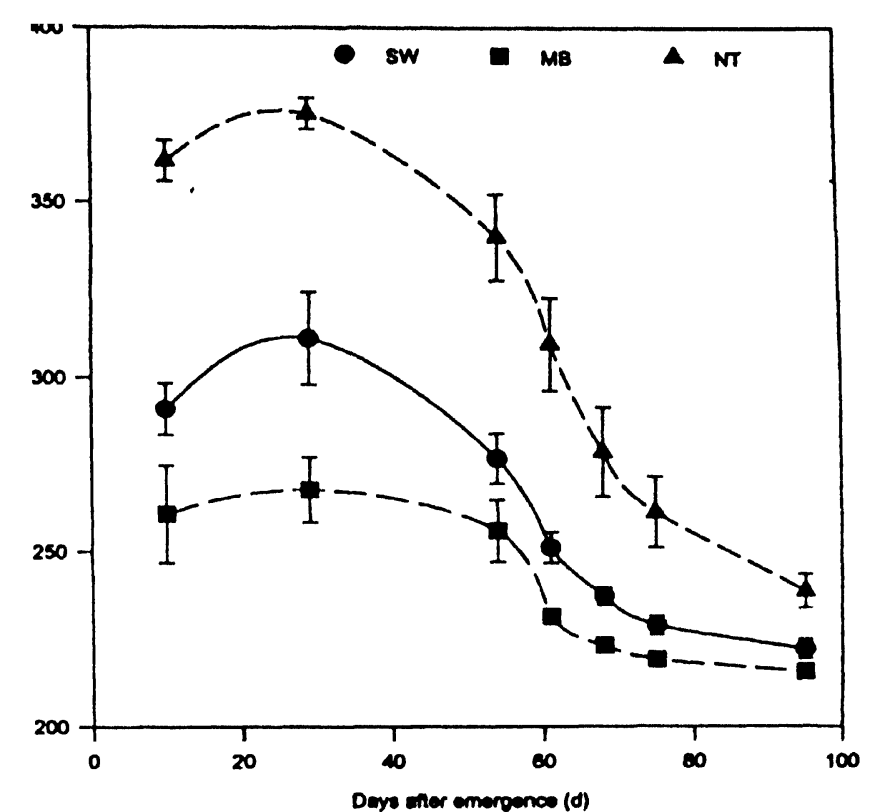

Fig. 1. Profile water content (0-1.5 $\mathrm{m}$ deep) at seven different days after emergence (DAE) of seedlings for unwetted sub-plots ( $\mathrm{PW}-$ ).

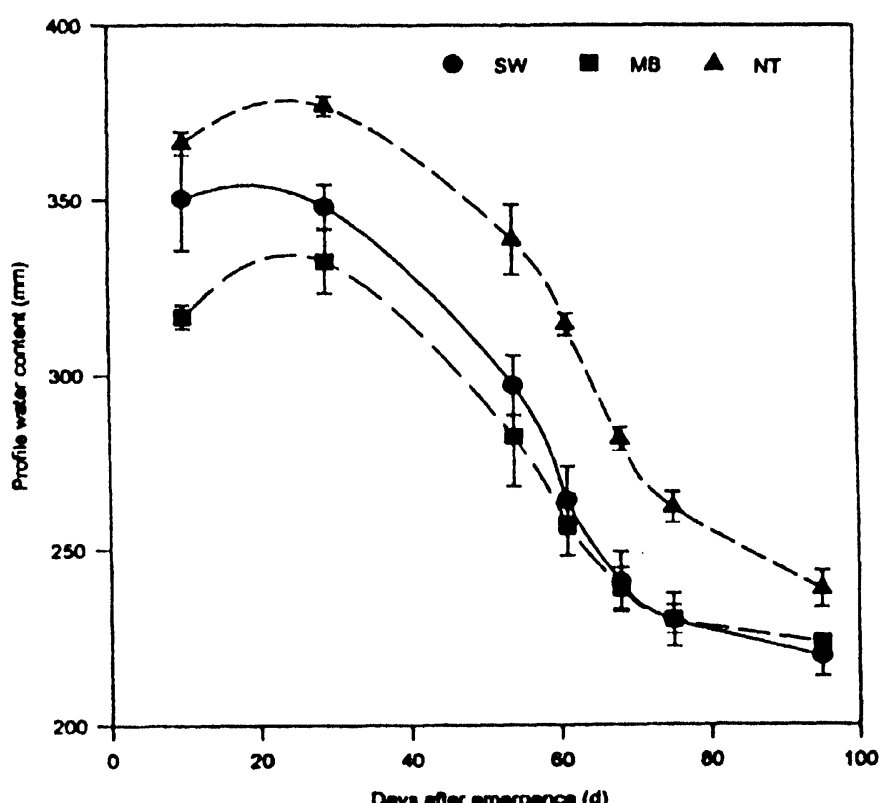

Fig. 2. Profile water content (0-1.5 $\mathrm{m}$ deep) at seven different days after emergence (DAE) of seedlings for wetted sub-plots $(\mathrm{PW}+)$.

imposed and 15 June 1993 when sorghum was planted, rainfall totaled $387 \mathrm{~mm}$. Precipitation was $252 \mathrm{~mm}$ during the 1993 cropping season, which was well below the 54-year average (Table 1). The shortfall in rains occurred mostly during 
Table 1

Monthly precipitation during the 1993 sorghum growing season and 54-year monthly means at Bushland, Texas

Month

$\begin{array}{ll}\begin{array}{l}\text { Precipitation } \\ (\mathrm{mm})\end{array} & \begin{array}{l}\text { 54-year mean } \\ (\mathrm{mm})\end{array}\end{array}$

June

July

August

October

Total

65
100
50
14
23
252

78

64

71
49

40

302

the critical crop growth and development stages (i.e. vegetative, flowering, and grain-filling) between August and October. During the cropping season the magnitude of profile water in the nonwetted sub-plots was of the order NT $>S W>M B$ (Fig. 1). The profile water content distribution at 95 DAE was similar for SW and $\mathrm{MB}$ treatments, but the soil under NT contained slightly more water than the other two treatments.

In sub-plots that were wetted before cropping $(P W+)$, there were no significant differences in water storage between SW and MB treatments throughout most of the growing season (Fig. 2). However, the water content in MB was less than in SW sub-plots at the first determination. The NT sub-plots contained more water than SW and MB sub-plots. The water content distribution was similar in SW and MB sub-plots starting at 29 DAE. Differences between treatments at 95 DAE were small even though NT sub-plots contained more water. The consistently greater amount of stored water in NT than in SW or MB plots was due to reduced evaporation and the water conservation effects of the mulch with NT (Phillips, 1984). Also, surface residues with NT reduced the impact of raindrops and retarded overland flow, thus enhancing water infiltration.

\subsection{Crop yields}

Sorghum grain yield after tillage (Table 2) was significantly greater with NT than with SW or MB. Grain yield was not different between the water treatments with NT because the profile water contents of NT/PW + were very similar to those of NT/PW - throughout the season (see Figs. 1 and 2). However, the grain yield was greater in PW + than in PW - with either SW or MB because the profile water content of SW/PW + sub-plots was significantly higher than that of SW/ PW - sub-plots from 10 DAE until 60 DAE. Beyond $60 \mathrm{DAE}$, water stored in the profile was not significantly different between SW/PW + and SW/PW - subplots. Also, the difference in profile water content of $\mathrm{MB} / \mathrm{PW}+$ and $\mathrm{MB} / \mathrm{PW}-$ sub-plots throughout the season accounts for the higher grain yield in $M B / P W+$ than in $\mathrm{MB} / \mathrm{PW}-$. The tillage $\times$ water interaction indicates that yields on NT/
Table 2

Sorghum grain and stover yields from three tillage systems and two water treatments

\begin{tabular}{llll}
\hline Treatment" & $\begin{array}{l}\text { Grain yicld } \\
\left(\mathrm{Mg} \mathrm{ha}^{-1}\right)\end{array}$ & $\begin{array}{l}\text { Stover yield } \\
\left(\mathrm{Mg} \mathrm{ha}^{-1}\right)\end{array}$ & $\begin{array}{l}\text { Harvest } \\
\text { index } \\
(\%)\end{array}$ \\
\hline SW/PW- & 1.3 & 3.1 & 28.6 \\
SW/PW+ & 2.5 & 3.9 & 39.6 \\
MB/PW- & 0.8 & 2.4 & 24.4 \\
MB/PW+ & 1.8 & 3.1 & 36.6 \\
NT/PW- & 3.4 & 3.7 & 47.4 \\
NT/PW+ & 3.5 & 3.2 & 52.1 \\
& & & \\
LSD & & 0.07 & \\
Tillage & 0.05 & 0.04 & \\
Water & 0.04 & 0.06 & \\
Tillage Xwater & 0.07 & & \\
\hline
\end{tabular}

- SW, sweep; Mb, moldboard; NT, no-tillage; PW, nonwetted sub-plots; PW +, prewetted sub-plots. b LSD $(P=0.05)$ values for tillage and water treatments are for comparison of main effect means; $L S D$ values for tillage $x$ water are for comparison of interaction means.

$\mathrm{PW}+$ plots and NT/PW - plots were greater than on either SW/PW + and SW/ $\mathrm{PW}$ - or $\mathrm{MB} / \mathrm{PW}+$ and $\mathrm{MB} / \mathrm{PW}$ - plots, respectively. Similar results, where additional stored water resulted in higher grain sorghum yields, have been reported by Unger (1984).

In PW - sub-plots, mean grain yield with NT was 4.4 times greater than with MB and 2.7 times greater than with SW. In PW + sub-plots, the mean grain yield with NT was only 1.9 times that with MB and 1.4 times that with SW. This difference in magnitude of grain yield of tillage treatments in PW + and PW - subplots reflects the relative magnitude of the difference in profile water storage in the tillage systems. Comparison of the differences between the profile water contents in Fig. 1 and Fig. 2 clearly shows larger differences between NT, SW, and MB in PW - sub-plots (Fig. 1) than in the same treatments in PW + sub-plots (Fig. 2). Mean stover yield in PW - sub-plots was 1.6 times larger with NT than with MB. Harvest index (i.e. mass of grain as a percentage of total yield (grain + stover) ) was greater in all PW + sub-plots than in PW - sub-plots. This indicates that with the availability of water, more assimilates were converted into grains than into stover. When a sorghum crop is drought-stressed, a relatively larger proportion of photosynthate goes into stover production. Table 2 indicates that stover yields with NT and SW as a result of tillage were greater than those with MB. Stover yields in PW + sub-plots were greater than in PW - sub-plots with each tillage treatment. This difference occurs because sorghum crops in PW + sub-plots had more water than those in PW - sub-plots, as indicated in Figs. 1 and 2. The NT/PW - stover yield was greater than either SW/PW - or MB $\mathrm{PW}$-. However, SW/PW + stover yield was greater than $\mathrm{NT} / \mathrm{PW}+$ or $\mathrm{MB} /$ $\mathrm{PW}+$ 


\subsection{Soil water extraction and evapotranspiration}

Soil water extraction (SWE) of sorghum as the result of tillage systems and water treatments was estimated from soil water measurements made on specific days after emergence. The integration of water content versus depth was done using the CSMP (1975) (Continuous System Modeling Program) software. The SWE increased slowly with all tillage treatments in the PW - and PW + sub-plots until a maximum was reached at about $60 \mathrm{DAE}$ (Figs. 3 and 4). Thereafter, SWE decreased rapidly as the crop matured and as the rainfall and profile water content decreased. In both the PW - and PW + sub-plots, peak SWE at about 58 DAE was greatest in NT, followed by SW and MB in that order. Crop had covered about $90-100 \%$ of the soil surface at $58 \mathrm{DAE}$. Therefore, we speculate that the transpiration component dominated the process of evapotranspiration (ET). The pan evaporation from a Class A pan ( $1.83 \mathrm{~m}$ diameter, $25 \mathrm{~cm}$ deep, elevated 10.2 $\mathrm{cm}$ above the ground surface) during the growing season (June to October) was $1261 \mathrm{~mm}$, giving an estimated potential evapotranspiration (PET) of $982 \mathrm{~mm}$. This estimated PET far exceeded the total rainfall (Table 1), indicating that water was very limiting during the growing season.

The trend of peak SWE in the order of NT $>\mathrm{SW}>\mathrm{MB}$ reflects the quantity of profile water (Figs. 1 and 2). Between 19 and 58 DAE, there was no difference in SWE rate among all tillage treatments. After $58 \mathrm{DAE}$, the SWE rate for NT sorghum was significantly greater than that for $\mathrm{SW}$ and $\mathrm{MB}$ sorghum. From 19 to $58 \mathrm{DAE}$, when there was sufficient moisture in the profile of both PW - and PW + sub-plots, there were no significant differences between SWE rates of

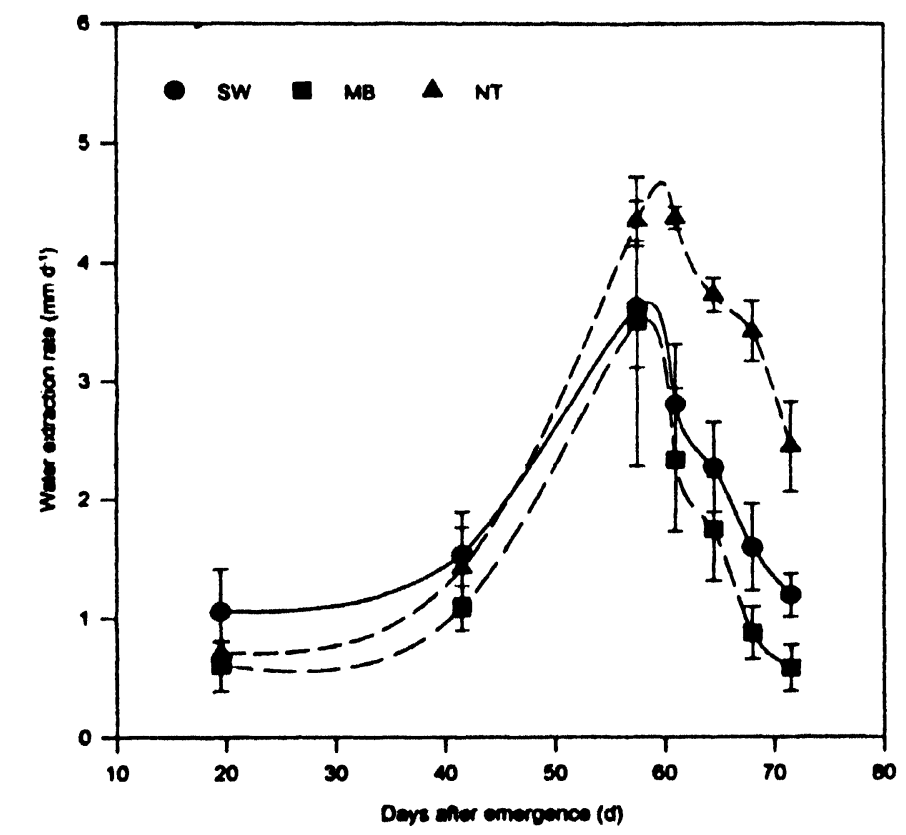

Fig. 3. Water extraction rate of sorghum grown under three tillage systems in unwetted sub-plots (PW-).

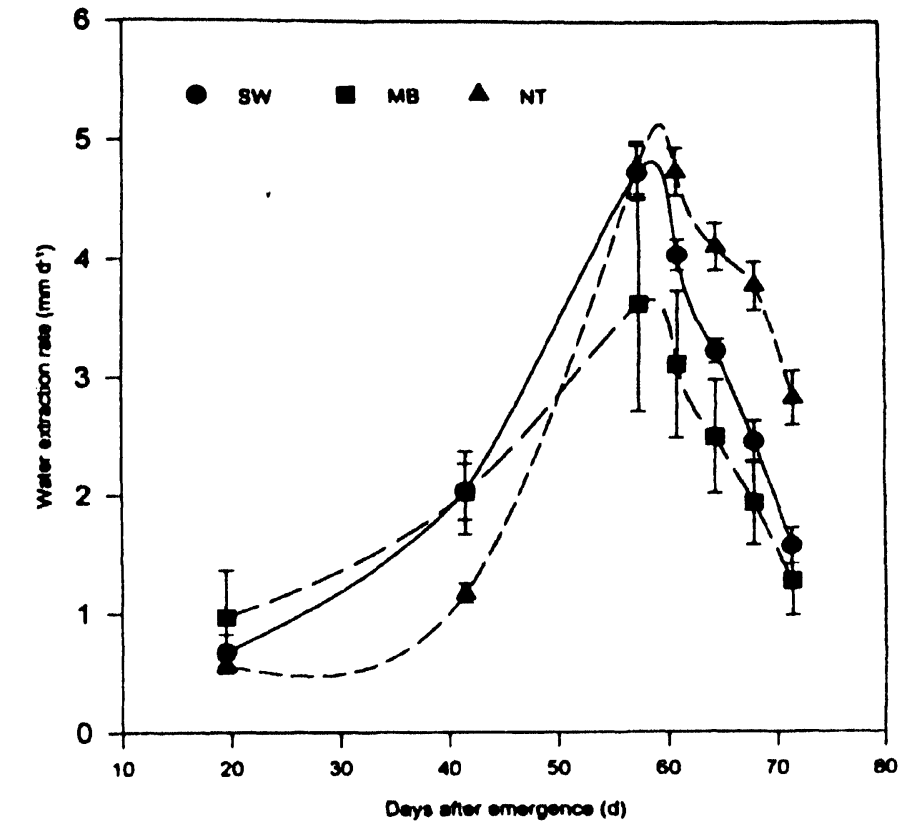

Fig. 4. Water extraction rate of sorghum under three tillage systems in wetted sub-plots ( $P W+$ ).

sorghum in the SW/PW - and SW/PW + sub-plots. After $58 \mathrm{DAE}$, when considerable differences in the profile water content of SW plots occurred (Figs. 1 and 2 ), the SWE rate of sorghum in SW/PW + was significantly greater than that in SW/PW - sub-plots. In the case of the MB tillage treatment, the SWE rate of sorghum in PW + sub-plots was significantly different from that in PW - subplots from $68 \mathrm{DAE}$ onwards. Because the profile water contents in NT/PW + and NT/PW - were similar, there was no difference in the SWE rates of sorghum on those treatments throughout the season. Cumulative ET between 10 and 95 DAE (Table 3) also shows that PW + sub-plots lost more water through TE than the PW - sub-plots, with the exception of the NT treatment. The PW - and PW + sub-plots of the NT treatment lost almost the same amount of water through ET. The standard errors of the cumulative ET in the PW - sub-plots of SW and MB reflect an inherent difficulty in using a neutron moisture meter to measure water content in relatively dry soils. The variability decreased considerably in wetter soils.

The relationship between sorghum biomass yield (grain + stover) and water used from 29 to 95 DAE is shown in Fig. 5. A linear equation $\left(r^{2}=0.79\right)$ was fitted to the relationship. Similar linear relationships have been reported in the literature (e.g. Ritchie, 1983). As water used for ET increased, above-ground biomass also increased. The results for grain yield are not shown, but they increased by over three-fold when ET increased from $40 \mathrm{~mm}$ to $140 \mathrm{~mm}$ during that period.

\subsection{Total nitrogen in grains and stover}

Protein is the principal nitrogenous component in seeds, and the total nitrogen content of sorghum grain differed among tillage treatments. The order of magni- 


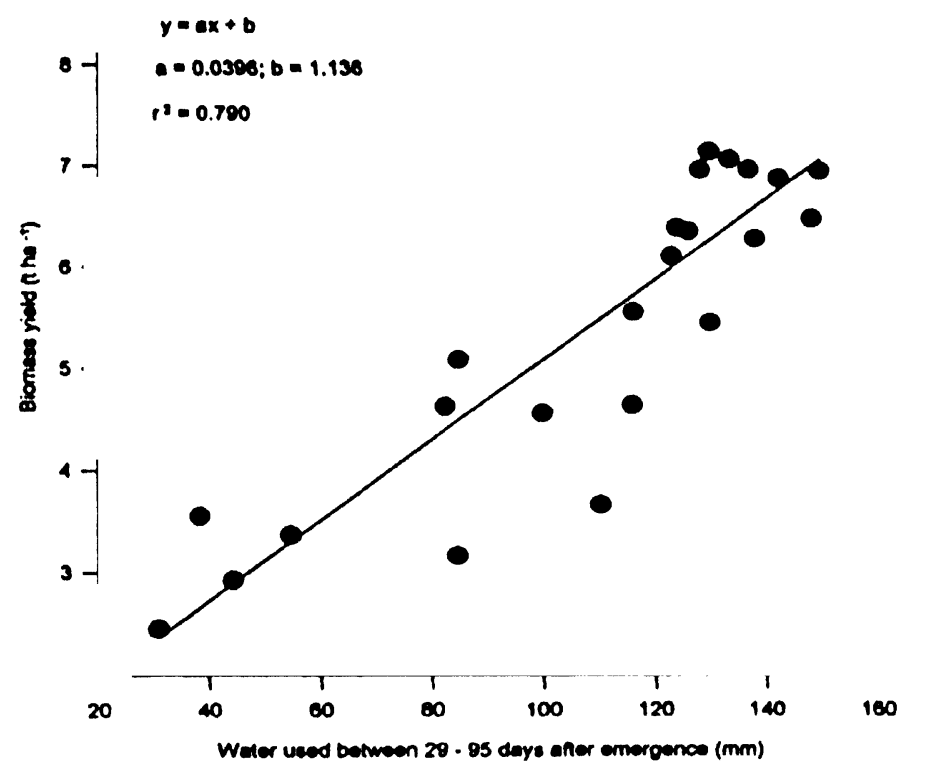

Fig. 5. Above-ground biomass yield versus water used by a sorghum crop between 29 and 95 DAE.

Table 3

Cumulative evapotranspiration of sorghum under three tillage and two water treatments between 10 and 95 days after emergence

\begin{tabular}{|c|c|c|}
\hline Tillage system" & Water treatment ${ }^{b}$ & $\begin{array}{l}\text { Evapotranspirpation }{ }^{\mathrm{c}} \\
(\mathrm{mm})\end{array}$ \\
\hline Sw & $\begin{array}{l}\text { PW- } \\
\text { PW+ }\end{array}$ & $\begin{array}{l}248.4 \pm 15.5 \\
287.9 \pm 5.0\end{array}$ \\
\hline MB & $\begin{array}{l}\text { PW- } \\
\text { PW+ }\end{array}$ & $\begin{array}{l}211.4 \pm 10.3 \\
268.4 \pm 7.6\end{array}$ \\
\hline NT & $\begin{array}{l}\text { PW- } \\
\text { PW+ }\end{array}$ & $\begin{array}{l}296.0 \pm 5.5 \\
297.5 \pm 3.3\end{array}$ \\
\hline
\end{tabular}

- SW, sweep; MB, moldborad; NT, no-tillage.

PW, nonwetted sub-plots; PW +, prewelled sub-plots.

c Mean of four plots with their standard errors.

tude of percent $\mathrm{N}$ in grain due to tillage treatments was $\mathrm{MB}>\mathrm{SW}>\mathrm{NT}$ (Table 4). As shown in Figs. 1 and 2, profile water storage with NT was greater than with either SW or MB. Our visual observations also confirmed that sorghum plants in MB and SW treatments were severely drought-stressed from 50 DAE onwards. The reduction of water in the soil profile under MB and SW resulted in a rapid decline of photosynthate in the crop from 50 DAE onwards as sorghum in those treatments became drought-stressed.

Based on the 1000-seed weight at harvest, grain from NT plots was heavier than that from SW plots. The 1000-seed weight of sorghum from the PW - sub-
Table 4

Seed weight and nitrogen concentration of grains and stover from sorghum grown using three tillage systems and two water treatments

\begin{tabular}{llll}
\hline Treatment" & $\begin{array}{l}\text { lo00-seed } \\
\text { weight } \\
(\mathrm{g})\end{array}$ & Percent nitrogen & \\
SW/PW- & 10.6 & Grain & Stover \\
SW/PW+ & 11.0 & 1.64 & 0.76 \\
MB/PW- & 11.7 & 1.64 & 0.60 \\
MB/PW+ & 10.4 & 1.98 & 0.99 \\
NT/PW- & 13.0 & 2.01 & 0.91 \\
NT/PW+ & 12.8 & 1.56 & 0.41 \\
& & 1.38 & \\
LSD & 1.93 & & 0.555 \\
Tillage & 0.90 & 0.502 & 0.162 \\
Water & 2.22 & 0.099 & 0.589 \\
Tillage $\times$ water & & 0.516 &
\end{tabular}

- SW, sweep; MB, moldboard; NT, no-tillage; PW, nonwetted sub-plots; PW +, prewetted sub-plots. - LSD $(P=0.05)$ values for tillage and water treatments are for comparison of main effect means LSD values for tillage $x$ water are for comparison of interaction means.

plots was not different from those in the PW + sub-plots (Table 4). The grain weight for NT/PW - sub-plots was significantly greater than for SW/PW - subplots. That for NT/PW + sub-plots was also greater than for MB/PW + sub-plots.

Although grain and stover yields with SW and MB tillage treatments were less than with the NT treatment (Table 2 ), the protein content (as measured by percent total N) of grain with MB was greater that than with NT. This accumulation of protein in plants under stress has been suggested by crop physiologists to be a protective mechanism; the application of proline helped wheat plants to recover from drought (Tyankova, 1967). Substantial accumulation of certain amino acids, especially proline, has been reported to occur concomitantly with drought stress in many plants, and probably relates to decreased protein synthesis resulting from that stress (Kessler, 1961). Except in NT, where the protein content (as reflected by percent total N) of grain from PW - sub-plots was greater than that from $\mathrm{PW}+$, the protein contents from the water treatments in SW and MB were not significantly different. The protein content of grain from $\mathrm{MB} / \mathrm{PW}+$ sub-plots was greater than that of grain from NT/PW + sub-plots.

As expected, the nitrogen content of stover was less than that of grain. There was no difference between the nitrogen contents of stover from the three tillage treatments. With the NT, the nitrogen content of stover was greater in PW - than in PW + sub-plots. The nitrogen contents of stover as a result of tillage $\times$ water interaction were not significantly different among treatments.

\subsection{Soil pH}

Trends of soil pH in water (Fig. 6) were similar in all tillage treatments. The pH ranged from 7.1 at a depth of $0-10 \mathrm{~cm}$ to 8.0 at about $60-90 \mathrm{~cm}$, indicating 


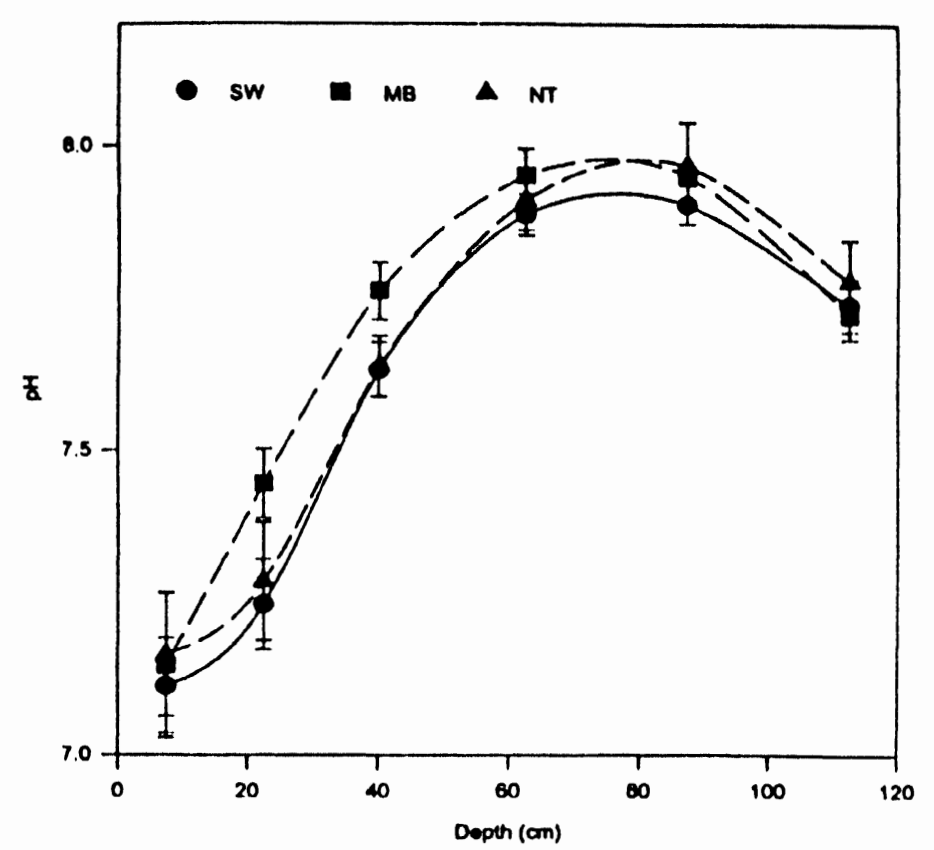

Fig. 6. pH in water for soil under three tillage systems before sub-plot treatments were imposed.

the presence of calcium carbonate in the soil profile. Soil pH increases with depth in Pullman soil are common (Unger and Pringle, 1981). Soil pH decreased to 7.7 at depths greater than $100 \mathrm{~cm}$. The soil pH at depths from 0 to $22.5 \mathrm{~cm}$ in the three tillage treatments ranged from 7.1 to 7.5 . The $\mathrm{pH}$ of soil in the MB treatment was higher than that of soil in either SW or NT. The pH range of 7.1-7.5 favours nutrient availability and therefore no nutrient deficiency symptoms were observed on the sorghum crop in any of the tillage treatments. Below a depth of $22.5 \mathrm{~cm}$, the soil $\mathrm{pH}$ in the three tillage treatments ranged from 7.5 to 8.0 , indicating the presence of free lime in the profile. At this $\mathrm{pH}$ range the availability of phosphorus, manganese, and zinc may be low. However, visual observation did not indicate any $\mathrm{P}, \mathrm{Mn}$, or $\mathrm{Zn}$ deficiency symptoms in the sorghum in any of the tillage treatments. The variation in $\mathrm{pH}$, as indicated by the standard error bars in Fig. 6, was larger at a depth of $0-15 \mathrm{~cm}$ in the MB treatment than for other depths, where the standard errors were too small to appear in the figure. It was expected that the soil pH under NT would be acidic because of the lack of mixing, which has been reported to increase the acidity of surface soil in no-tillage systems, particularly if fertilizers are used (Blevins et al., 1985). Our experiment did not show such increases in acidity, probably because of the short duration of the experiment and the absence of fertilizer application.

\subsection{Organic carbon}

The organic carbon contents of the soil profiles under the three tillage systems were similar at depths greater than $15 \mathrm{~cm}$ (Fig. 7). At a depth of $0-15 \mathrm{~cm}$, however, the organic carbon content with NT $\left(14.0 \mathrm{~g} \mathrm{~kg}^{-1}\right)$ was larger than that with

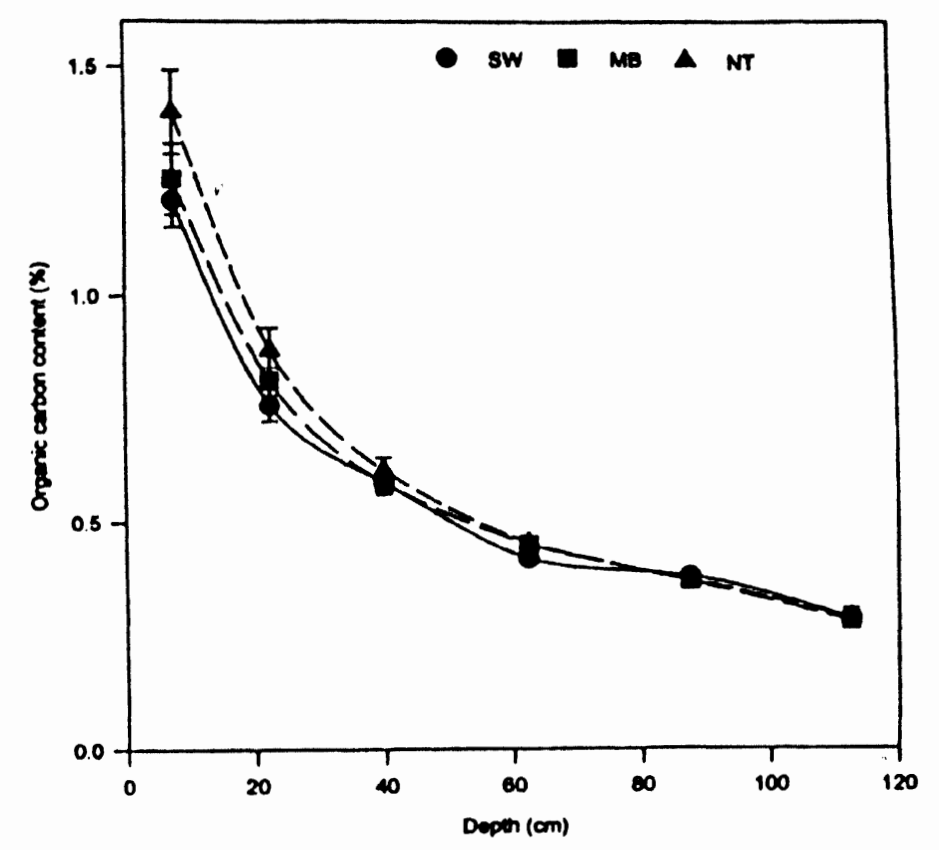

Fig. 7. Organic carbon content of soil under three tillage systems before planting.

SW $\left(12.1 \mathrm{~g} \mathrm{~kg}^{-1}\right)$ or $\mathrm{MB}\left(12.5 \mathrm{~g} \mathrm{~kg}^{-1}\right)$. These organic carbon content values are within the range of $9-38 \mathrm{~g} \mathrm{~kg}^{-1}$ normally found in Mollisols. The greater surface soil organic carbon content in the NT system is ascribed to the established fact that ploughing increases the rate of organic matter loss from soils (Blevins et al., 1985 ). The consequence of this loss of organic matter in SW and MB treatments is that soil aggregate stability declines, resulting in a tendency of the soil to slake upon wetting and crust when dry. In the long term, the increase in surface soil organic carbon content in NT systems will stimulate changes in the biological and physical processes occurring in soil.

There was a greater variation in the organic carbon content of the surface soil, as shown by the standard error bars in Fig. 7, than for soil at depths greater than $30 \mathrm{~cm}$. The variation in the organic carbon content of the surface soil was due to uneven mixing of organic matter during tillage in SW and MB plots. In the case of NT, the variability of the organic carbon content was because of the variation in space of the distribution of herbage (residue), and the decomposition and incorporation of this residue in the soil. The variation in organic carbon content in the surface soil was larger for both MB and NT than for SW.

\subsection{Soil nitrate and exchangeable ammonium}

The $\mathrm{NO}_{3}^{-}-\mathrm{N}$ contents in soil as a result of the tillage treatments (Fig. 8 ) indicate that moldboard ploughing increases the $\mathrm{NO}_{3}^{-}-\mathrm{N}$, particularly in the surface $0-15 \mathrm{~cm}$, probably because of increased mineralization. The order of magnitude of $\mathrm{NO}_{3}^{-}-\mathrm{N}$ in the soil profile under the three tillage systems was $\mathrm{MB}>\mathrm{SW}>\mathrm{NT}$. The total $\mathrm{NO}_{3}^{-}-\mathrm{N}$ in the soil profile to a depth of $125 \mathrm{~cm}$ in $\mathrm{MB}$ was estimated 


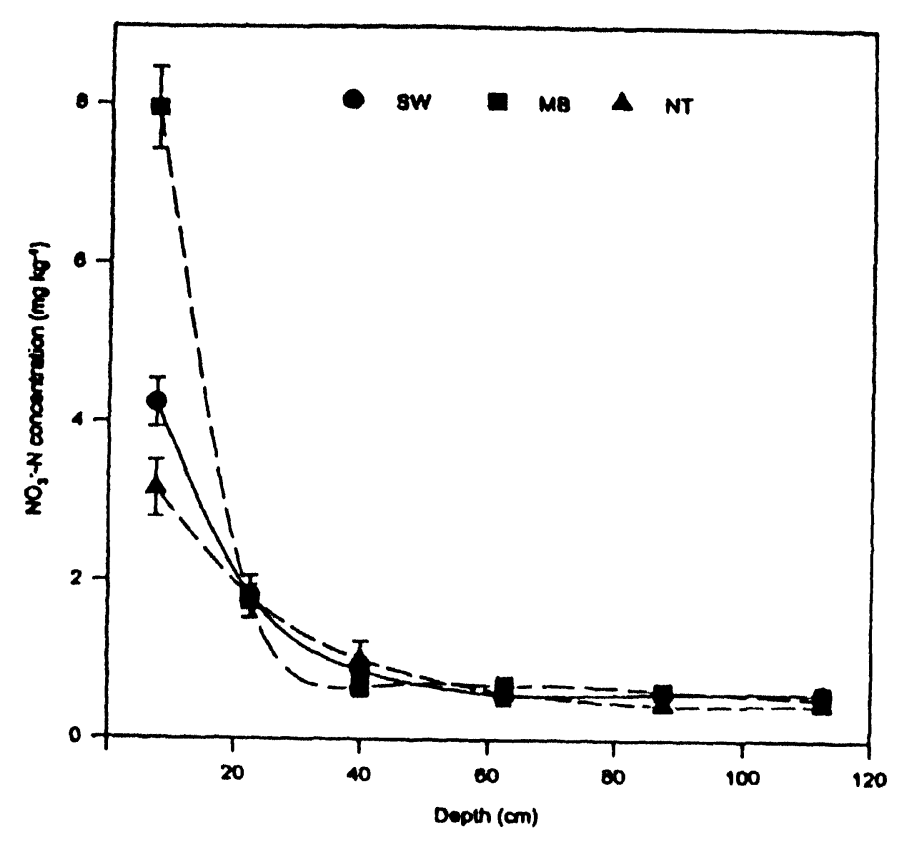

Fig. 8. $\mathrm{NO}_{3}^{-}-\mathrm{N}$ concentration distribution in soil under three tillage systems before sub-plot treatments were imposed.

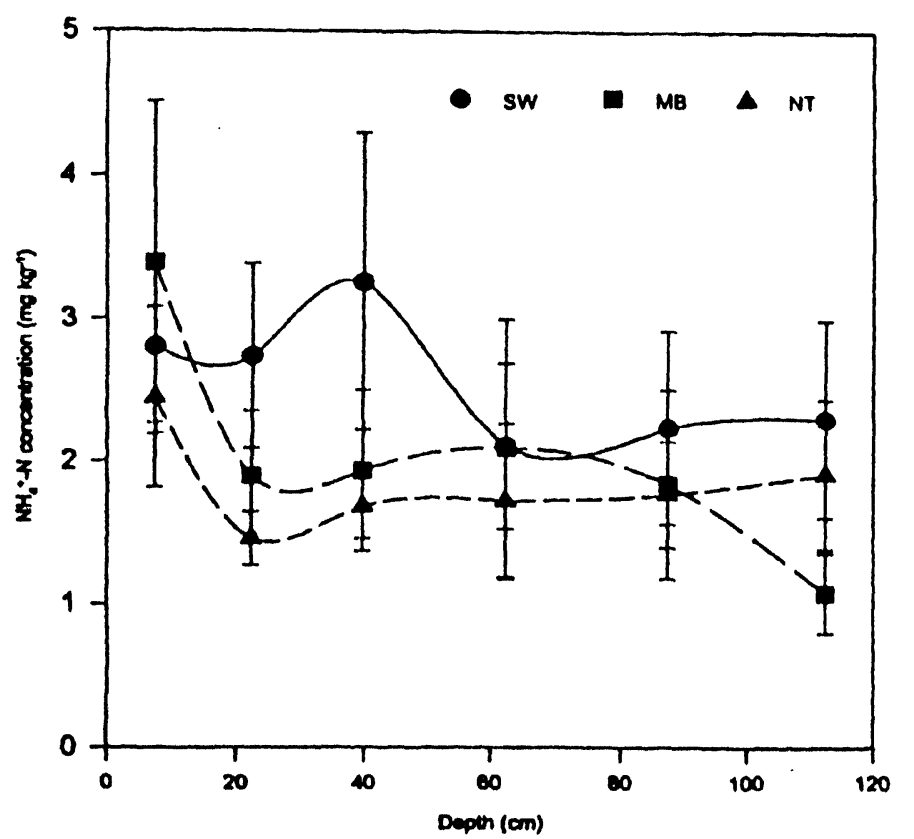

Fig. 9. $\mathrm{NH}_{4}^{+}-\mathrm{N}$ distribution in the soil profile under three tillage systems before sub-plot treatments were imposed.

from Fig. 8 to be $23.6 \pm 0.34 \mathrm{~kg} \mathrm{ha}^{-1}$, followed by SW with $18.8 \pm 2.02 \mathrm{~kg} \mathrm{ha}^{-1}$ and $\mathrm{NT}$ with $16.1 \pm 1.69 \mathrm{~kg} \mathrm{ha}^{-1}$. These $\mathrm{NO}_{3}^{-}-\mathrm{N}$ values are within the range of those obtained by Eck and Jones (1992) for this soil. Nitrogen sufficiency values for grain sorghum at fruiting growth stage are $<2.5 \% \mathrm{~N}$ as deficient, $2.5-3.0 \% \mathrm{~N}$ as low, $3.0-4.0 \% \mathrm{~N}$ as normal, and $>4.0 \% \mathrm{~N}$ as high (Lockman, 1972). Using a mean bulk density of $1.32 \mathrm{Mg} \mathrm{m}^{-3}$ for all soil down to $1.25 \mathrm{~m}$, these $\mathrm{NO}_{3}^{-}-\mathrm{N}$ sufficiency limits correspond to $<4.13 \times 10^{5} \mathrm{~kg} \mathrm{~N} \mathrm{ha}^{-1}$ as deficient, $4.13 \times 10^{5}$ to $4.96 \times 10^{5} \mathrm{~kg} \mathrm{~N} \mathrm{ha}^{-1}$ as low, $4.96 \times 10^{5}$ to $6.62 \times 10^{5} \mathrm{~kg} \mathrm{~N} \mathrm{ha}^{-1}$ as normal, and $>6.62 \times 10^{5} \mathrm{~kg} \mathrm{~N} \mathrm{ha}^{-1}$ as high. Using these criteria and the percentage values of nitrogen in grains and stover (Table 4), the soil under all the tillage treatments was considered to be deficient in $\mathrm{NO}_{3}^{-}-\mathrm{N}$. However, nitrogen deficiency symptoms were not observed with the sorghum crop during the season. The reason for lower $\mathrm{NO}_{3}^{-}-\mathrm{N}$ in the NT treatment is not clear. Although leaching may be involved (Eck and Jones, 1992), transformation of soil $\mathrm{N}$ by micro-organisms may also have been a factor. Since the rate of organic matter decomposition is normally increased by ploughing (Blevins et al., 1985), the conversion of organic $N$ to plant available inorganic $\mathrm{N}$ should be slower in the NT treatment. The facts that (a) rainfall during the cropping season was low (Table 1 ), and (b) at no time during the season (Figs. 1 and 2) was the soil profile under any of the treatments saturated lead us to conclude that the lower concentrations of $\mathrm{NO}_{3}^{-}-\mathrm{N}$ in the NT soils may have been the result of decreased $N$ mineralization rate rather than to leaching. Indirect evidence from other studies (e.g. Burford et al., 1981) supports this conclusion.

Except at a depth of $30-50 \mathrm{~cm}$ for the SW treatment, the distribution of exchangeable $\mathrm{NH}_{4}^{+}-\mathrm{N}$ in the soil profile under the three tillage systems (Fig. 9) did not show any significant differences. Fig. 9 shows that the $\mathrm{NH}_{4}^{+}-\mathrm{N}$ at a soil depth of $0-125 \mathrm{~cm}$ was $30.1 \pm 8.71 \mathrm{~kg} \mathrm{~N} \mathrm{ha}^{-1}$ for $\mathrm{MB}, 38.5 \pm 10.69 \mathrm{~kg} \mathrm{~N} \mathrm{ha}^{-1}$ for $\mathrm{SW}$, and $26.8 \pm 4.62 \mathrm{~kg} \mathrm{~N} \mathrm{ha}^{-1}$ for NT tillage systems. Addition of these $\mathrm{NH}_{4}^{+}-\mathrm{N}$ estimates to the $\mathrm{NO}_{3}^{-}-\mathrm{N}$ figures still indicated that these soils were deficient in $\mathrm{N}$ when compared with the $\mathrm{N}$ sufficiency values of Lockman (1972). The absence of visual $\mathrm{N}$ deficiency symptoms on the sorghum crop on the tillage systems may be because of the soil's larger total $\mathrm{N}$ pool, which releases sufficient quantities of $\mathrm{N}$ for crop growth during the season. Further are necessary studies on mineralization and availability of $N$ to sorghum on this soil. The variability associated with the exchangeable $\mathrm{NH}_{4}^{+}-\mathrm{N}$ measurements, as indicated by the standard error bars in Fig. 9, is large and probably indicates the spatial variability of this soil property.

\section{Conclusions}

Virgin lands and revegetated lands will continue to be converted to croplands in the future to increase food production. Because it is a major input, and impacts soil properties and sustainable agricultural production, selection of appropriate tillage systems for any agroecological region is imperative. From this study, we found that more water was stored in the soil profile with NT than with SW and MB tillage systems. This stored water, in turn, resulted in both sorghum grain and stover yield increases with NT as compared with MB and SW. However, the percent nitrogen was higher for MB and SW than for NT sorghum. 
The greater soil organic carbon content of NT as compared with other treatment plots has important implications for the biological, chemical, and physical processes that continually occur in the soil under NT. In the long term, greater organic carbon content should improve the soil structure and maintain at a greater level the population and activities of soil fauna (Blevins et al., 1985; Hendrix et al., 1990). Based on this study, we conclude that NT is the better choice of the three tillage systems for converting revegetated lands to cropland in locations where soil water is limiting.

\section{Acknowledgement}

The assistance of L. J. Fulton, Biological Technician, USDA-Agricultural Research Service, Bushland, TX, in conducting this study is gratefully acknowledged.

\section{References}

Baumhardt, R.L., Zartman, R.E. and Unger, P.W., 1985. Grain sorghum response to tillage method used during fallow and to limited irrigation. Agron. J., 77: 643-646.

Blevins, R.L., Frye, W.W. and Smith, M.S., 1985. The effects of conservation tillage on soil properties. In: F.M. D'Itri (Editor), A Systems Approach to Conservation Tillage. Lewis, MI, PW-A, pp. 99 110.

Burford, J.R., Dowdell, R.J. and Crees, R., 1981. Emission of nitrous oxide to the atmosphere from direct-drilled and ploughed clay soils. J. Sci. Food Agric., 32: 219-223.

CSMP (Continuous System Modeling Program), 1975. Continuous System Modeling Program III (CSMP III). Reference Manual. Program Number 5734-XS9, International Business Machines (CSMP III). Reference

Eck, H.V. and Jones, O.R., 1992. Soil nitrogen status as affected by tillage, crops, and crop sequences. Agron. J., 84: 660-668.

Hargrove, W.L. and Hardcastle, W.S., 1984. Conservation tillage practices for winter wheat production in the Appalachian Piedmont. J. Soil Water Conserv., 39: 324-326.

Hendrix, P.F., Crossley, D.A., Jr., Blair, J.M. and Coleman, D.C., 1990. Soil biota as components of sustainable agroecosystems. In: C.A. Edwards, R. Lal, P. Madden, R.H. Miller and G. House (Editors), Sustainable Agricultural Systems. Soil Water Conservation Society, Ankeny, IA, pp. 637654.

Jackson, M.L., 1958. Soil Chemical Analysis. Prentice-Hall, Englewood Cliffs, NJ, 498 pp.

Kampshake, L.J., Hannah, S.A. and Cohen, J.M., 1967. Automated analysis for nitrate by hydrazine reduction. Water Resour. Res., 1: 205-216.

Keeney, D.R. and Nelson, D.W., 1982. Nitrogen - Inorganic Forms.In: A.L. Pagc, R.H. Miller and D.R. Keeney (Editors), Methods of Soil Analysis. Part 2. Chemical and Microbiological Properties. 2nd edn. Agronomy 9, American Society of Agronomy, Madison, WI, pp. 643-698.

Kessler, B., 1961. Nucleic acids as factors in drought resistance in higher plants. Recent Adv. Bot., 2 : $1153-1159$.

ockman, R.B., 1972. Mineral composition of grain sorghum plant samples. Part III. Suggested nutrient sufficiency limits at various stages of growth. Commun. Soil Sci. Plant Anal., 3: 295-304. Nelson, D.W. and Sommers, L.E., 1973. Determination of total nitrogen in plant material. Agron. J. 65: 109-112.

Phillips, R.E., 1984. Soil moisture. In: R.E. Phillips and S.H. Phillips (Editors), No-tillage Agriculture: Principles and Practices. Van Nostrand Reinhold, New York, pp. 66-86.
Ramig, R.E. and Mazurak, A.P., 1964. Wheat stubble management. I. Influence on some physical properties of a Chernozem soil. Soil Sci. Soc. Am. Proc., 28: 554-557.

Ritchie, J.T. 1983. Efficient water use in crop production: Discussion on the generality of relations between biomass production and evapotranspiration. In: H.M. Taylor, W.R. Jordan and T.R. Sinclair (Editors), Limitations to Eficient Water Use in Crop Production. American Society of Agir (Ex) Society of America, Soil Science Society of America, WI, pp. 29-44.

Atation Ans 2. SAS Inst. Inc., Cary, NC.

Technicon Autoanalyzer II 1977. Individual/simultaneous determination of nitrogen and/or phosphorus in BD acid digests. Technicon Industrial Systems, Tarrytown, NY, 10 pp.

Tyankova, L.A., 1967. Influence of proline on the sensitivity of wheat plants to drought. Chem. Abstr. 66: 100902.

Unger, P.W., 1984. Tillage and residue effects on wheat, sorghum, sunflower grown in rotation. Soil Sci. Soc. Am. J., 48: 885-891.

Unger, P.W. and Pringle, F.B., 1981. Pullman soils: Distribution, importance, variability, and management. Texas Agric. Exp. Stn., College Station, Bull. B-1372, 23 pp. 